\title{
BIOLOGICKÝ ÚČINEK ULTRAFIALOVÉHO ZÁŘENÍ
}

\author{
12: 480-486, 2010 \\ ISSN 1212-4117 \\ Zuzana Freitinger Skalická1, Zdeněk Hon ${ }^{2}$, Leoš Navrátil ${ }^{2}$ \\ 1Jihočeská univerzita v Českých Budějovicích, Zdravotně sociální fakulta, katedra radiologie \\ a toxikologie \\ 2České vysoké učení technické v Praze, Fakulta biomedicínského inženýrství v Kladně, katedra lékař- \\ ských a humanitních oborů
}

\section{ÚVOD}

Kosmické záření se dělí na tři složky: galaktické záření, sluneční záření a záření radiačních (van Allenových) pásů Země. Galaktické záření pochází z hlubokých oblastí vesmíru a skládá se $z$ protonů $(85 \%)$, jader helia $(11 \%)$, těžších jader prakticky všech prvků soustavy $(1 \%)$ a elektronů (3\%). Sluneční kosmické záření pochází především ze slunečních erupcí. Je tvořeno z $99 \%$ protony, těžší nabité částice představují méně než $0,1 \%$ celkové intenzity. Radiační (van Allenovy) pásy jsou tvořeny protony a elektrony zachycenými magnetickým polem Země v určitých vzdálenostech od jejího povrchu; vnější pás je ve vzdálenosti 20000 km, vnitřní pás ve vzdálenosti $3000 \mathrm{~km}$ (Kuna, 2005). Ze Slunce na Zem dopadá mimo jiné optické záření, které je součástí elektromagnetického vlnění. Optické záření je složeno z 50 \% viditelného světla, ze $45 \%$ infračerveného záření a z 5 \% UV záření. UV záření je elektromagnetické vlnění se stejnou fyzikální povahou jakou má světlo, liší se pouze vlnovou délkou, která je menší než vlnové délky světla (Navrátil, Rosina, 2005).

\section{Fyzikální vlastnosti UV záření}

Slunce vyzařuje široké spektrum vlnových délek elektromagnetického záření - gama, RTG, UV, viditelné a infračervené záření (obr. 1). Terestriální záření (sluneční záření dopadající na zemský povrch) je filtrováno průchodem atmosférou a neobsahuje vlnové délky kratší než 290 nm (Kuna, 2005). Proto na zemský povrch dopadají především tři typy záření: UV záření o vlnových délkách 100-400nm, viditelné záření o vlnových délkách 400-760 nm a infračervené záření o vlnových délkách 760-3000 nm. Intenzita UV záření se výrazně zvyšuje odrazem z takových povrchů, jako je voda, sníh či písek. Např́klad suchý plážový písek může odrazit 15 -20\%, mořská vlna 10-20\% UV záření. Do hloubky půl metru pod vodou se dostává $40 \%$ UV záření dopadajícího na vodní hladinu (Ultraviolet radiation and human health, 2009).

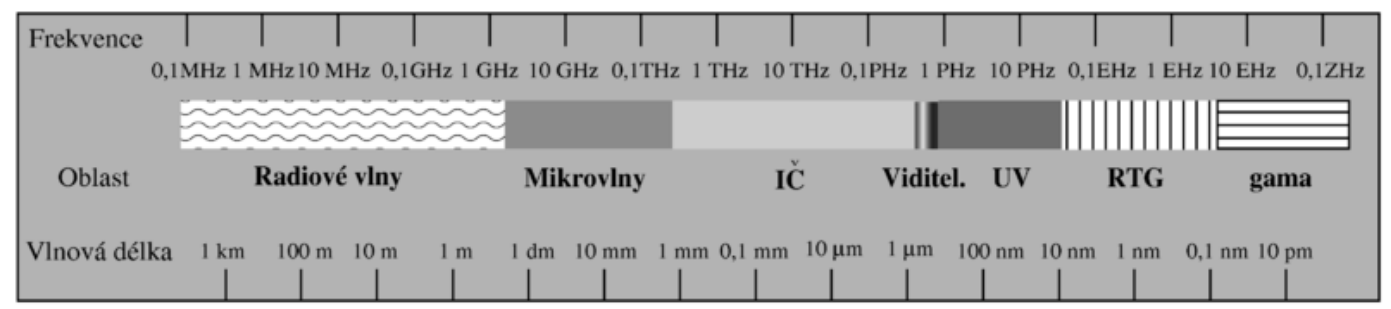

Obrázek 1 Spektrum elektromagnetického záření (převzato z www.wikipedia.org)

UV záření můžeme rozdělit podle biologických účinků do tří skupin (Kožní fototypy, 2008):

- Dlouhovlnné UVA záření $(\lambda=315-400$ $\mathrm{nm})$
Tvoři $4 \%$ z paprsků, které dopadají na zemský povrch. Toto záření způsobuje vznik erytému a pigmentace kůže. Oproti UVB záření proniká do hlubších vrstev kůže. Použivá se mimo jiné $\mathrm{v}$ soláriích. 
Toto pásmo muže být ještě členěno: UVA - I $(\lambda=340-400 \mathrm{~nm})$ a UVA - II $(\lambda=320$ $-340 \mathrm{~nm})$.

- Stredněvlnné UVB záření $(\lambda=280-315 \mathrm{~nm})$ je považováno za biologicky nejvýznamnější. Způsobuje erytém, vznik pigmentace kůže a také se podílí na vzniku různých typů kožních nádorů. $V$ terestriálním záření tvoří necelé $1 \%$. Stejně jako UVA záření je využíváno $\mathrm{k}$ fototerapii.

- Krátkovlnné UVC záření $(\lambda<280$ nm) je někdy nazýváno germicidním. Používá se např́klad $\mathrm{k}$ dezinfekci operačních sálů. Oproti ostatním pásmům má nejvyšší energii, tomu také odpovídají jeho největší biologické účinky. Na zemský povrch se nedostává, protože je filtrováno ozonovou vrstvou. Jeho podíl na karcinogenezi je minimální.

\section{Biologické účinky UV záření}

Biologické účinky UV záření závisí na energii fotonů, intenzitě záření, době trvání ozáření, schopnosti absorpce záření tkání a na reaktivitě organismu.

\section{Pozitivní účinky UV záření}

Významným účinkem je syntéza vitaminu D, který se tvoří $\mathrm{v}$ kủži působením slunečního záření z provitaminu 7-dehydrocholesterolu, derivátu cholesterolu. UV záření štěpí $\mathrm{B}$ jádro sloučeniny za vzniku cholekalciferolu, tedy vitaminu $\mathrm{D}_{3}$. Význam vitaminu $\mathrm{D}$ je $\mathrm{v}$ účasti při resorpci vápníku a fosfátu ze střeva, čímž přispívá $\mathrm{k}$ regulaci a optimalizaci hladiny těchto prvků v krvi, které jsou důležité pro stavbu kostí. Nedostatek vitaminu D se projevuje změknutím kostí $\mathrm{v}$ důsledku ztrát a nedostatečné resorpce vápníku a fosfátu. U dětí se tento nedostatek projevu jako křivice, u dospělých pak jako osteomalacie. Rovněž se projevuje i zvýšenou kazivostí zubů.

\section{Negativní účinky $U V$ záření}

Mezi negativní účinky UV záření patří tzv. fotodermatózy, což je skupina onemocnění spojených s přecitlivělostí vůči UV záření. Dělí se na dvě hlavní skupiny - fotodermatózy vyvolané vnějšími faktory (fototoxické a fotoalergické reakce) a na syndromy spojené s nestabilitou
DNA (napr. Xeroderma pigmentosum) (Xeroderma pigmentosum, 2007).

Fototoxické reakce mohou postihnout jakoukoli osobu a jejich vznik závisí na koncentraci vyvolávající látky. Principem je přímé poškození buněk chromoforem po jeho aktivaci zářením (nejvíce se uplatňuje UVA, méně UVB záření a viditelné světlo). Zpočátku vzniká vystupňovaná erytémová reakce, otok a puchýře, později se objevuje pigmentace. Jako chromofory se často uplatňují různé celkové či místně podávané léky (TTC - Tri-creatine citrate, antirevmatika, barbituráty, acridin aj.). Vyvolavatelem může být také kontakt s některými rostlinami, jako je bolševník (Hanoušková, Plecháček, 2010) nebo aplikace parfémů (Rostová, 2006).

Fotoalergické reakce jsou daleko vzácnější a postihují jen vnímavé jedince. Jako fotoalergen se může uplatnit mnoho látek, zejména lokálně aplikovaných. Časté jsou antibakteriální látky (chlorhexidin), voňavky (santalový olej, syntetické pyžmo), ale i některé sunscreeny (PABA) a léčiva (chlorpromazin). PABA (kyselina para-aminobenzoová) je vitamin, který zastupuje skupinu B komplexů. Účinná je po sloučení s kyselinou pantotenovou a je součástí kyseliny listové. Jako součást vitaminů ze skupiny B komplexu je rozpustná ve vodě. Chrání pokožku proti slunečnímu UV záření. Kromě toho brání mutaci těch epidermálních buněk, které mohou být nekancerogenní (Rostová, 2006).

„Photoaging“ zahrnuje makro- i mikroskopické kožní změny, které jsou zpơsobeny chronickým slunečním zářením. Nejedná se o prosté urychlení stárnutí jako u velmi starých lidí (90 let a více), kteři se celý život vyhýbali slunění a jejich kůže je hladká, neposkvrněná, vykazující ztenčení, ztrátu elasticity a prohloubení normálních ohybových rýh. Naproti tomu u padesátiletých lidí se světlou kůží, kteří se celý život vystavovali slunci, se vyskytuje velké množství vrásek, žlutavá, suchá kůže s různými benigními, premaligními nebo i maligními novotvary (Ettler, 2009).

\section{Maligní onemocnění}

Nejvážnější zdravotní dopad účinků UV záření na kủži představují kožní zhoubné nádory. Tzv. aktinické keratózy představují plošné rohové novotvary, které mohou být př̀edstupněm pro vznik bazaliomu a spinaliomu. Zatímco bazali- 
om roste destruktivně v místě vzniku, spinaliom již metastázuje i do vnitřních orgánů. Oba nádory jsou závislé na celoživotní expozici UV zářením a objevují se většinou až ve stárí. $\mathrm{Na}$ proti tomu melanom, nádor $\mathrm{z}$ pigmentotvorných buněk, může vznikat na kưži po celý život (výjimečně i $\mathrm{v}$ dětstvî), a to spíše na základě akutních solárních popálení vedoucích až k puchýŕům (Arenbergerová, Arenberger, 2005).

Nádory kůže se dělí:

- Melanomové (maligní melanom) - nádor vzniká z buněk produkujících pigment (melanocyty).

- Bazocelulární karcinom (BCC) - nádor vzniká z bazálních buněk.

- Spinocelulární karcinom (SCC) - nádor vzniká z buněk pokožky (keratinocyty).

- Ostatní - jiné druhy jsou méně časté.

\section{Bazocelulární karcinom}

Jde o nejčastější maligní kožní nádor. Jeho výskyt se $\mathrm{v}$ posledních 15 letech zdvojnásobil. Př́čina onemocnění je stejně jako u dalších zhoubných onemocnění nejasná. Hlavním etiologickým faktorem je chronické, dlouhodobé vystavování kůže UV záření.

\section{Spinocelulární karcinom}

$\mathrm{V}$ malém procentu metastázuje především do regionálních lymfatických uzlin. Zvýšené riziko metastázování mají nádory větší než $2 \mathrm{~cm}$, málo diferencované tumory, nádory rtu a boltce.

\section{Maligní melanom}

Je nejzhoubnější nádorové onemocnění kủže. Maligní melanom není častým onemocněním, představuje jen 5-7 \% všech zhoubných kožních nádorů. Agresivita nádoru však řadí melanom mezi nejzávažnější maligní onemocnění vůbec. Rozlišují se čtyři základní morfologické formy maligního melanomu:

1) Povrchově se šírící maligní melanom

Patří k nejčastějším typům melanomu. Tvoř́ zhruba $65 \%$ těchto nádorů. Roste nejprve povrchově a v pozdější fázi začne pronikat také do hlubších vrstev kůže. $\mathrm{Na}$ kůži se takový růst projevuje vytvořením hrbolku na tmavě hnědé až černé plošce.

2) Nodulární melanom

Pro tuto formu kožního melanomu je od počátku charakteristický patrný hrbol vyvý- šený nad okolní kưži, který rovněž signalizuje, že nádor prorůstá do větší hloubky kůže. Tvoří zhruba $20 \%$ všech melanomů.

3) Lentigo maligna melanom

Vzniká na kůži s patrnými známkami poškození slunečním zářením. Jedná se o plošná ložiska, na nichž se střídají světlejší a tmavší odstíny hnědé barvy. Nejčastěji se objevuje u starších osob.

4) Akrolentiginózní melanom

Akrolentiginózní melanom je forma, která vzniká především na periferních partiích lidského těla, typicky na ploskách či dlaních nebo pod nehty. Je záludná $\mathrm{v}$ tom, že může zpočátku vypadat jako bradavice, modřina či mozol (Arenbergerová, Arenberger, 2005).

\section{Ochrana proti UV záŕení}

Stínění a oděv jsou nejefektivnější ochranou proti účinkům UV záření. Je však nutné počítat i s odraženým světlem. Ochrana oděvem je závislá na jeho barvě. Nejlépe chrání barevné oděvy, které pohlcují nejen více UV záření, ale i viditelného světla a infračerveného záření. Nevýhodou tohoto jevu je neprŕjemné zahřivaní oděvu. Tenké, bílé nebo dokonce vlhké tkaniny chrání méně. Syntetické materiály (nylon, dacron apod.) propouštějí méně UV záření než bavlněná vlákna. Některé oděvy mají dokonce od výrobce deklarovaný UPF (UV protecting factor), který udává propustnost pro UV záření. UPF nad 50 znamená vynikající ochranu. Je doporučovaný zejména u malých dětí, které se často pohybují na slunci.

Nejúčinnější ochranou očí jsou brýle s tzv. UV filtrem. Existují čtyři normalizované kategorie filtrů: kategorie 0 - bezbarvý nebo velmi světlý filtr; kategorie 1 - světlý filtr; kategorie 2 - středně tmavý filtr; kategorie 3 - tmavý filtr, nevhodný pro řízení motorových vozidel; kategorie 4 - velmi tmavý filtr, nevhodný pro řízení motorových vozidel (UV záření a kontaktní čočky, 2007).

\section{Systémová ochrana}

Tento způsob ochrany se ordinuje jen při některých fotodermatózách. Jedná se např́klad o antimalarika, léky ovlivňující prostaglandiny a karotenoidy. Nejvíce se používá beta-karoten, který má současně i antioxidativní účinky. Podávání beta-karotenu je založeno na jeho selektiv- 
ní akumulaci v podkožní tukové tkáni, která dovoluje, aby tento pigment (rozptýlený jak $\mathrm{v}$ epidermis, tak $\mathrm{v}$ dermis) účinkoval jako membránový stabilizátor a vychytávač různých forem reaktivního kyslíku, které jsou vyvolány UV ozářením (Ettler, 2001).

\section{Aktivní ochrana}

Mezi aktivní ochranu se řadí tzv. fotoprotektivní adaptace a fotochemoprotekce.

- Fotoprotektivní adaptace znamená opakované (6-10×) ozáření UV zářením těsně podprahovými dávkami, které podpoři prrirozené mechanismy (Ettler et al., 1997).

- Fotochemoprotekce zahrnuje použití př́pravku s nízkým obsahem látky 5-MOP a zároveň UV-B absorbujícího sunscreenu (SPF 6-8) spolu s expozicí přirozeným slunečním světlem nízkých dávek. 5-MOP (5-methoxypsoralen neboli bergapten) patří mezi furokumariny, fytotoxické látky, které jsou účinné jak $\mathrm{v}$ prímém kontaktu s pokožkou, tak po perorálním užití. Po ozáření UVB zářením ve vlnových délkách 230-380 nm se stávají pro člověka toxické. Kombinace všech tři faktorů vyvolá mírné

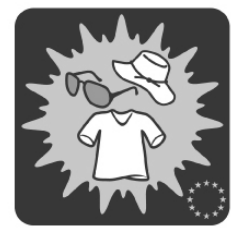

Chraňte se oděvem, klobouk a brýle poskytujî další ochranu.

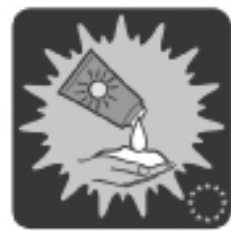

Aplikujte ochranné prostř̌edky v dostatečném množství a opakovaně

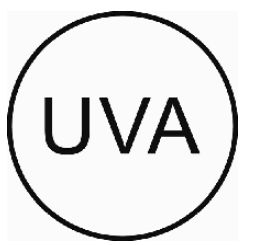

Prostředek poskytuje ochranu proti UVA v požadované výši. ztluštění stratum corneum (nejvrchnější vrstva epidermis) a produkci melaninu (Rostová, 2006).

\section{Pasivní ochrana}

Sunscreeny jsou látky, které ochraňují lidskou kưži před působením UV záření. Tyto př́pravky jsou dodávány v podobě roztoků, gelů, krémů. Doporučení Evropské komise 2006/647/ES zavádí nové požadavky na způsob značení výše ochrany, který je srozumitelný pro spotřebitele. Nově musí každý prostředek zajistit nejen ochranu proti UVB záření, ale i ochranu proti UVA záření. Ochrana proti UVA záření musí představovat minimálně jednu třetinu hodnoty udávané pro ochranu proti UVB. Pro značení výše ochrany proti UVB se používaji 4 kategorie: nízká (SPF 6-10), střední (SPF 15-25), vysoká (SPF 30-50) a velmi vysoká SPF (50+). Kromě značení kategorie je možno nadále uvádět i konkrétní hodnotu SPF (sun protection factor) (Ettler, 2006).

Pro dobrou srozumitelnost varování doporučuje Komise použít následující piktogramy (obr. 2) (převzato z http://www.dolceta.eu/ceska-republika/Mod3/spip.php?article380).

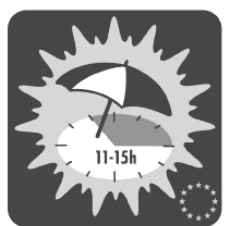

Vyvarujte se slunečnímu záření $\mathrm{v}$ době poledne.

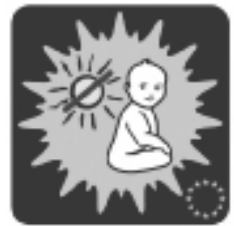

Nevystavujte kojence a malé děti př́mému slunci.

Obrázek 2 Piktogramy 


\section{Kožní fototypy a přirozená ochrana}

Je všeobecně známo, že reakce na slunění není u každého člověka zcela stejná. Lidská kůže vykazuje určité rasové odchylky, které se projevují zejména odlišnou barvou. Každý člověk by měl proto znát fototyp své kůže, aby se mohl účinně chránit. Podle jednotlivých typů je odvozen tzv. bezpečný čas pro první expozici na slunci bez reakce. U prvního typu je to 5-10 minut, u druhého typu 10-20 minut, u třetího typu 20-30 minut a u čtvrtého typu až $40 \mathrm{mi}-$ nut. Tyto hodnoty platí pro dospělé osoby. Kojenci by měli být před sluncem chráněni a děti do tř́ let by měly být na slunci minimálně (Ettler, 2001).

Tabulka 1 Kožní fototypy - typy kůže a jejich reakce na sluneční záření

\begin{tabular}{|c|c|c|c|}
\hline Typ kůže & Označení & Reakce na slunění & Ochranná reakce kůže \\
\hline $\begin{array}{c}\text { I. } \\
\text { (kůže nápadně světlá, } \\
\text { pihy husté, vlasy rezavé, } \\
\text { oči modré, zřídka hnědé, } \\
\text { prsní bradavky velmi } \\
\text { světlé) }\end{array}$ & Keltský typ (2\%) & vždy těžký & $\begin{array}{c}\text { žádná, červená kůže bez } \\
\text { pigmentace, za 1-2 dny } \\
\text { se loupe }\end{array}$ \\
\hline $\begin{array}{l}\text { II. } \\
\text { (kůže trochu tmavší než } \\
\text { I., pihy řídké, vlasy blond } \\
\text { až hnědé, oči modré, } \\
\text { zelené, šedé, prsní bra- } \\
\text { davky světlé) }\end{array}$ & $\begin{array}{l}\text { Evropan se světlou } \\
\text { pletí }(12 \%)\end{array}$ & vždy silný & $\begin{array}{c}\text { velmi slabá pigmentace, } \\
\text { kůže se loupe }\end{array}$ \\
\hline $\begin{array}{c}\text { III. } \\
\text { (kůže světlá nebo světle } \\
\text { hnědá, pihy žádné, pig- } \\
\text { mentové névy hnědé, } \\
\text { prsní bradavky tmavšî) } \\
\text { IV. } \\
\text { (kůže světle hnědá nebo } \\
\text { olivová, pihy žádné, pig- } \\
\text { mentové névy tmavé, } \\
\text { vlasy tmavé, oči tmavé, } \\
\text { prsní bradavky tmavé) }\end{array}$ & $\begin{array}{l}\text { Evropan s tmavou } \\
\text { kưží }(78 \%)\end{array}$ & téměř nikdy & $\begin{array}{c}\text { rychlá reakce, hluboká } \\
\text { pigmentace }\end{array}$ \\
\hline
\end{tabular}

(Zdroj: Jirásková, M. Světlo 4, 2007)

\section{Opalování v soláriích}

Světová zdravotnická organizace se v srpnu 2004 obrátila na vlády zemí, které se nově staly členy EU s informací o své iniciativě v oblasti prevence poškozování zdraví vlivem UV záření při opalování v soláriích. Používané př́stroje vyzařují UVA a UVB záření, obojí poškozuje DNA v buňkách kůže. UVB o vlnové délce 295 -320 nm má velmi dobře známé karcinogenní účinky a vede k rozvoji novotvarů na kůži. Současné vědecké studie dokazují, že vysoké dávky dlouhovlnného UVA záření se na tvorbě karci- nomu podílejí. V zásadě solária emitují především UVA a malou dávku UVB. V posledních letech jsou ozařovací lampy vyráběny tak, že produkují více UVB, aby se přblížily slunečnímu spektru a urychlilo se opálení (Lajčíková, 2005). Nové studie prokazují závislost mezi užíváním solária a výskytem maligního melanomu, bazocelulárního karcinomu kůže a skvamózní formy karcinomu kưže. Je široce rozšířen omyl, že opálení získané v soláriu chrání kưži před spálením při letním pobytu na slunci. Ve skutečnosti toto opálení chrání proti slu- 
nečnímu spálení jen v omezené míre. Opálení ze solária poskytuje ochranu srovnatelnou s nízkým ochranným faktorem (SPF 2-3).

Mezinárodní komise pro ochranu před neionizujícím zářením doporučuje vyhnout se návštěvě solária:

- lidem mladším než 18 let;

- těhotným ženám;

- lidem s teplotou nebo užívajícím jakékoliv léky (nutná konzultace s lékařem);

- osobám s pokožkou, která se špatně opaluje a je pokryta velkým počtem névů (víc než 30);

- osobám, které mají tendenci $\mathrm{k}$ tvorbě pih a v minulosti se na slunci spálily;

- osobám s prekancerózami (např. solární keratózy) nebo které měly v minulosti maligní kožní léze či sluněním poškozenou pokožku (vrásky ve tváři, nepravidelné pigmentové skvrny na tváŕi či na rukou);

- nepoužívat $\mathrm{v}$ soláriích kosmetiku, která zvyšuje citlivost vưči UV záření (zejména parfémy) (Lajčíková, 2005).

\section{ZÁVĚR}

Schopností UV záření je rozkládat makromolekulární látky a $\mathrm{v}$ důsledku toho poškozovat živočišné buněčné struktury, včetně nosičů genetických informací DNA a RNA. UV záření může na lidské pokožce vyvolávat řadu chemických a biologických reakcí, které se v závislosti na celkové absorbované dávce projevují různým stupněm zánětu pokožky - od tvorby erytému přes vznik puchýřů až k nekróze tkáně. Proto je doporučováno lidem sledovat tzv. UV-index, což je mezinárodně standardizovaná bezrozměrná veličina charakterizující úroveň erytémového slunečního ultrafialového záření dopadající na zemský povrch, vyjadřující biologický efekt na lidské zdraví. Používá se $\mathrm{k}$ informovanosti obyvatelstva o možném negativním vlivu UV záření na lidský organismus (Ultraviolet radiation and human health, 2009). Dlouhodobé působení UV záření může na kưži vyvolat i chronické změny, které již mohou být do jisté míry nevratné - aktinické stárnutí kůže (photoageing) a narušení imunitních reakcí (fotoimunosuprese), které se mohou spolupodílet na rozvoji rakoviny kůže (fotokarcinogeneze). Nejvážnější zdravotní dopad účinků UV záření na kůži představují kožní zhoubné nádory. Tzv. aktinické keratózy představují plošné rohové novotvary, které mohou být předstupněm pro vznik bazaliomu a spinaliomu. Oproti tomu melanom, nádor $\mathrm{z}$ pigmentotvorných buněk, může vznikat na kưži po celý život spíše na základě akutních solárních popálení až do puchýř̀u. Je z kožních nádorů nejnebezpečnější, protože rychle metastázuje. Maligní melanom se vyskytuje stále častěji. Za posledních třicet let stoupl počet př́padů v ČR $4 \times$. Muži a ženy jsou postiženi téměř stejnou měrou (někteři autoři uvádějí větší výskyt u žen $\mathrm{v}$ poměru 1,5:1 (Hercogová, 2010). Na základě výše uvedených skutečností je v současné době kladen velký důraz na prevenci a ochranu před UV zářením.

* Tento článek byl podpořen grantovou agenturou „Fond rozvoje vysokých škol Ministerstva školství, mládeže a télovýchovy ČR“. Název projektu: „Edukační materiál pro výuku předmétů se zaměrením na mechanizmy účinků ionizujícího a neionizujícího zárení", číslo projektu 2/2010.

\section{LITERATURA}

ARENBERGEROVÁ, M., ARENBERGER, P.: Maligní melanom kůže. [online]. 2005 [cit. 2010-09-15]. Dostupné z: http://www.melanomy.cz/?touch=malignimelanom Elektromagnetické spektrum [online]. 2010[cit. 2010-0709]. Dostupné z: http://cs.wikipedia.org/wiki/ Soubor:ElmgSpektrum.png

ETTLER, K.: Ochrana kůže před účinky ultrafialového záření - Fotobiologické sekce [online]. 2001 [cit. 2010-05 -13]. Dostupné z: http://www.lfhk.cuni.cz/dermat/ verze_cz/sekce_fotobiologicka_abstrakta_01.htm

ETTLER, K.: Moderní fotoprotekce. Zdravotnické noviny. [online]. 2006 [cit. 2010-09-14]. Dostupné z http:// www.zdn.cz/clanek/priloha-lekarske-listy/modernifotoprotekce-173679

ETTLER, K.: Návod k použití: UV zárení a lidská kůže Spektrum kožních obtǐzi je široké. [online]. 2009 [cit. 2010-09-14]. Dostupné z: http://www.angis.cz/ angis_revue_clanek.php?CID=96

ETTLER, K., LÁZNÍČKOVÁ, P., NOŽIČKOVÁ, M.: Minimální erytémové dávky UV-B záření. Cs. Derm., 1997, vol. 72. no 2, s. 60-62.

HANOUŠKOVÁ, I., PLECHÁČEK, J.: Parsnip in the Environment. [online]. 2010 [cit. 2010-07-27]. Dostupné z: http://www.seps.sk/zp/casopisy/zp/2001/zp2/ hanousko.htm

HERCOGOVÁ, J.: Co je melanom? Česká akademie dermatovenerologie. [online]. 20 [cit. 2010-09-15]. Dostupné z: http://www.dermanet.cz/cs/kozni-choroby/ melanomy/ 
Jaké jsou předpisy pro výrobky určené $k$ ochraně proti slunečnímu zárenení? [online]. 2010[cit. 2010-09-09]. Dostupné z: http://www.dolceta.eu/ceska-republika/Mod3/ spip.php?article380

KUNA, P., NAVRÁTIL, L. a kol.: Klinická radiobiologie. Praha, Manus 2005.

Kožní fototypy [online]. 2008[cit. 2010-06-12]. Dostupné z: http://www1.szu.cz/chzp/koupani/slunce3.html

LAJČ́́KOVÁ, A.: WHO kproblematice opalování v soláriích [online]. 2005 [cit. 2010-09-09]. Dostupné z: www.1.szu.cz/svi/PDF/biblio2005.pdf

NAVRÁTIL, L., ROSINA, J.: Medicínská biofyzika. Praha, Grada 2005.

ROSTOVÁ, J. a kol.: Vybrané akutní účinky UV záření na organismus. Vojenské zdravotnické listy. 2006, vol. 75, no 1 , s.17-24.
Xeroderma pigmentosum [online]. 2007[cit. 2010-07-10]. Dostupné z:

http://www.medicabaze.cz/index.php?

sec $=$ term_detail\&categId $=9$ \& cname $=$ Dermatovenerologi e\&letter $=X \&$ termId $=555 \&$ tname $=$ Xeroderma + pigmentos um\&h=empty\#jump

UV zárení a jeho vliv na oko [online]. 2007 [cit. 2010-07-

20]. Dostupné z: http://www.cocky-online.cz/uv-zareni-aoko

UV záření a kontaktní čočky [online]. 2007 [cit. 2010-0724]. Dostupné z: http://www.videni.cz/kontaktni-cocky/ info/111-uvzareni

Ultraviolet radiation and human health. World Health Organisation. [online]. 2009 [cit. 2010-09-14]. Dostupné z: http://www.who.int/mediacentre/factsheets/fs305/en/

Zuzana Freitinger Skalická et al. zuzana.skalicka@centrum.cz 